\title{
Soft law in environmental matters and the role of the European Courts: too much or too little of it?
}

Citation for published version (APA):

Eliantonio, M. (2018). Soft law in environmental matters and the role of the European Courts: too much or too little of it? Yearbook of European Law, 37, 496-524. https://doi.org/10.1093/yel/yey011

Document status and date:

Published: 01/01/2018

DOI:

10.1093/yel/yey011

Document Version:

Publisher's PDF, also known as Version of record

Document license:

Taverne

Please check the document version of this publication:

- A submitted manuscript is the version of the article upon submission and before peer-review. There can be important differences between the submitted version and the official published version of record.

People interested in the research are advised to contact the author for the final version of the publication, or visit the DOI to the publisher's website.

- The final author version and the galley proof are versions of the publication after peer review.

- The final published version features the final layout of the paper including the volume, issue and page numbers.

Link to publication

\footnotetext{
General rights rights.

- You may freely distribute the URL identifying the publication in the public portal. please follow below link for the End User Agreement:

www.umlib.nl/taverne-license

Take down policy

If you believe that this document breaches copyright please contact us at:

repository@maastrichtuniversity.nl

providing details and we will investigate your claim.
}

Copyright and moral rights for the publications made accessible in the public portal are retained by the authors and/or other copyright owners and it is a condition of accessing publications that users recognise and abide by the legal requirements associated with these

- Users may download and print one copy of any publication from the public portal for the purpose of private study or research.

- You may not further distribute the material or use it for any profit-making activity or commercial gain

If the publication is distributed under the terms of Article $25 \mathrm{fa}$ of the Dutch Copyright Act, indicated by the "Taverne" license above, 


\title{
Soft Law in Environmental Matters and the Role of the European Courts: Too Much or Too Little of It?
}

\author{
Mariolina Eliantonio*
}

\section{Introduction}

Environmental policy entered the EU Treaties with the Single European Act. The Maastricht Treaty significantly changed and strengthened the provisions on environmental law and policy, as it made environmental protection an explicit aim of the European Community (EC), now European Union (EU), and empowered the Council to adopt environmental measures by qualified majority voting and no longer unanimity. ${ }^{1}$ Since the entry into force of the Treaty in 1993, EC (now EU) activity in the field of environmental policy has accelerated, resulting in an impressive body of legislative and non-legislative measures, which includes, according to the Commission, more than 200 pieces of EU legislation. ${ }^{2}$ Some legislation is sector-specific covering water, air, nature, waste, noise, and chemicals. Other measures are horizontal in nature and cut across all environmental sectors, for example, environmental impact assessments, access to environmental information, public participation in environmental decision making, and liability for environmental damage.

Many of these measures deal with extremely technical issues, for example standards for pollutants such as ozone, particulate matter, and nitrogen dioxide, the requirements to ensure that surface waters in the EU keep a 'good ecological status' and a 'good chemical status' or the adequate conservation measures to preserve a certain natural habitat. Because of the consequent difficulties in the interpretation and application of the relevant pieces of EU law for national administrations, the environmental field has seen an impressive growth in the

\footnotetext{
* Mariolina Eliantonio, Maastricht University, PO Box 616 6200, MD. Tel: +31 43 3883189; Email: m.eliantonio@maastrichtuniversity.nl

${ }^{1}$ Subsequent treaties have not made significant changes as regards environmental policy. The Lisbon Treaty, however, did introduce Art. 3(2) TEU, which reads: '[T]he Union shall establish an internal market. It shall work for the sustainable development of Europe ... aiming at ... a high level of protection and improvement of the quality of the environment.' In addition, Art. 19(1) TFEU has added fighting climate change to the aims the environmental policy of the EU.

$2<$ http://ec.europa.eu/environment/basics/benefits-law/applying-eu-law/index_en.htm> accessed 18 October 2018.
} 
use of soft law measures. These measures come in the various forms of guidance documents, Commission notes, interpretative communications, and so on.

The recurrent and widespread use of soft law documents has sparked a very intense academic debate which is of relevance beyond the field of environmental policy. Importantly, it has been considered that the legal effects of soft law cannot be clearly determined, ${ }^{3}$ and that this uncertainty is clearly at odds with the proposition that the EU is 'a Community based on the rule of law'. ${ }^{4}$ Furthermore, there are no rules concerning the publication of soft law, making its dissemination and accessibility at best questionable. ${ }^{5}$ The procedure for the adoption of soft law may be characterized by 'an (extreme) lack of transparency'. 6 Moreover, since soft law is not geared towards establishing new policies and legislation, the minimum consultation requirements set in the Commission Guidelines on Impact Assessment ${ }^{7}$ do not apply to soft law. ${ }^{8}$ This makes soft law shaky from the point of view of input legitimacy, since those who will be affected by it do not have any chance to influence its content.

Additionally, the use of soft law instruments can allow the Commission to escape Council, Parliament, or comitology oversight which would be obligatory under the procedures set up to issue delegating and implementing acts. ${ }^{9}$ It has also been argued that specific legitimacy risks arise when the Commission interprets EU soft law in a-too-flexible and subjective manner, creating confusion about and sometimes even adding to the existing legal obligations' ${ }^{10}$

It can also be questioned whether soft law, because of its non-binding nature, is able to achieve the objective of the uniform application of EU law. In fact, it has been suggested that EU soft law might even run counter to that objective. This is because of the confusion over the legal effects of soft law measures which may arise in the national authorities' and courts' minds. ${ }^{11}$

Finally, it has been noted that, by taking soft law instruments into account, the European courts can broaden the scope of EU competences, thereby altering the extent of the obligations for Member States arising from primary law. ${ }^{12}$ In particular, it has been argued that the use of soft law in court may have the effect of transforming soft law into hard law, since the European courts may recognize certain legal effects to soft law measures, thereby endowing soft law measures

${ }^{3}$ L Senden, Soft Law in European Community Law (Oxford: Hart Publishing, 2004), 461 and ff.

${ }^{4}$ Case 294/83, Parti écologiste "Les Verts" v European Parliament ECLI:EU:C:1986:166, para. 23.

5 Senden (n 3), 496-497.

6 L Senden, 'Soft Post-Legislative Rulemaking: A Time for More Stringent Control' (2013) European Law Journal, 65.

${ }^{7}$ Commission Staff Working Document, Better Regulation Guidelines COM(2015), 19 May 2015, Chapter III.

8 Senden (n 6), 69-9.

9 Senden (n 6), 58.

${ }^{10} \mathrm{~L}$ Senden and A van den Brink, Checks and Balances of Soft EU Rule-Making, available at <http:// www.europarl.europa.eu/activities/committees/studies.do?language=EN >,16.

11 Ibid 16-17.

12 Senden (n 3), 393-7. 
with hard law effects. ${ }^{13}$ It has also been considered that this process of hardening can happen through recognition by the court of the fact that certain general principles of law, such as legitimate expectations and legal certainty, operate in connection with soft law measures. ${ }^{14}$ Snyder has considered that the interplay between hard law and soft law may result in the granting of certain legal effects to soft law measures, when the court refers to a soft law measure in a ruling and the Commission later uses that ruling. In this way, 'soft law, based partly on a court judgment, is transformed into hard law by administrative decision'. ${ }^{15}$ The hardening of soft law through judicial practice can be considered as problematic not only for the purposes of the rule of law, but also because of the other problems highlighted above connected to soft law making, ie its legitimacy deficit. The claim is, therefore, that the Court of Justice is 'fostering illegitimate ways of decision-making and thus widens the democratic deficit of the European Union'. ${ }^{16}$

Interestingly, the soft law debate has also witnessed an opposite claim: instead of engaging too much with soft law, the Court of Justice has been 'accused' of not engaging sufficiently with it. In particular, it has been argued that, because of the legitimacy concerns highlighted above, the Court of Justice ought not to be 'fooled' by the seemingly non-binding nature of soft law and review soft law measures which are able to produce legal effects. ${ }^{17}$ This is because soft law measures do have an influence on Member States' behaviour and, as long as an allegedly unlawful soft law measure is not annulled, it remains lawful and is capable of generating indirect legal effects, by imposing, for example, new legal obligations upon Member States and other parties that are not as such contained in the underlying primary or secondary enabling EU measure. ${ }^{18}$

Despite the serious potential legal consequences attached to the use of soft law by the European Courts (or the lack thereof), the issue has, so far, received little academic attention, especially from an empirical point of view. ${ }^{19}$ This paper aims partially to fill this academic gap by examining the ways in which the European courts treat soft law measures stemming from EU environmental legislation.

\footnotetext{
13 See e.g. E Korkea-aho, 'EU Soft Law in Domestic Legal Systems: Flexibility and Diversity Guaranteed?', (2009) Maastricht Journal of European and Comparative Law, 277, <https://doi. org/10.1177/1023263X0901600302>.

${ }^{14} \mathrm{H}$ Hofmann, 'Negotiated and Non-Negotiated Administrative Rule-Making-The Example of EC Competition Policy' (2006), Common Market Law Review, 165.

${ }^{15}$ F Snyder, 'Soft Law and Institutional Practice in the European Community', in S Martin (ed.), The Construction of Europe (Dordrecht: Springer, 1994), 197-225, at 216.

${ }^{16} \mathrm{O}$ Stefan, Soft Law in Court. Competition Law, State Aid and the Court of Justice of the European Union (Alphen aan den Rijn: Kluwer Law International, 2012), 22.

${ }^{17} \mathrm{~J}$ Scott, 'In Legal Limbo: Post-Legislative Guidance as a Challenge for European Administrative Law' (2011) Common Market Law Review, 329-55, at 331-2.

18 Senden (n 6), 66.

${ }^{19}$ Apart from the general overview provided by Senden (n 3), see Stefan (n 16).
} 
Environmental policy is an interesting case study in this respect because of the wealth of soft law measures as well as the fact that, as mentioned above, the environment is an area that can be extremely technical and can change rapidly in light of scientific advances. These factors render the need for explanatory documents in the form of soft law measures an almost indispensable tool for the Member States that need to transpose and apply EU environmental legislation.

This paper will first provide a definition of soft law and the scope of the analysis will be clarified. Thereafter, the methodology will be explained. Sections 3 and 4 will provide quantitative as well as qualitative analysis of the use made of soft law by the Court of Justice of the European Union (CJEU) in environmental matters. These two analytical sections will show that soft law is hardly referred to, has never been challenged, and is generally acknowledged as nonbinding. Section 5 will conclude by responding to the two claims discussed above concerning the use that European courts have made or ought to make of environmental soft law.

\section{Definitions, scope of the analysis, and methodology}

In the following, soft law will be used in the definition given by Senden, as 'rules of conduct that are laid down in instruments which have not been attributed legally binding force as such, but nevertheless may have certain (indirect) legal effects, and that are aimed at and may produce practical effects'. ${ }^{20}$

Taking the environmental field and reviewing the sub-areas within this policy field where the EU has enacted legislation, the sample of Directives listed in Table 1 and corresponding soft law measures have been selected. ${ }^{21}$

These Directives can be considered as representative because of their relative importance in the field of environmental law. Moreover, this selection constitutes a mix of older and newer directives as well as directives which are the products of a more 'traditional' way of EU law making (such as the Habitats Directive) and directives which can instead be ascribed to the category of experimentalist governance (such as the Water Framework Directive). ${ }^{22}$ Finally, there are more 'substantive' directives and more 'procedural' directives (such as the EIA and SEA Directives).

\footnotetext{
${ }^{20}$ Senden (n 3), 112. See Senden also (ibid. 219-20) for a possible categorization.

${ }^{21}$ Please note that the research is updated to 1 July 2018. Legislative materials and case law after this date is not taken into account. The list of the selected soft law measures are contained in Annex I. 22 On experimentalism, especially with regard to environmental law and the Water Framework Directive, see I von Homeyer, 'Emerging experimentalism in EU environmental governance' in C Sabel and C Zeitlin (eds), Experimentalist Governance in the EU: Towards a New Architecture (Oxford: Oxford University Press, 2010); E Korkea-aho, 'Watering Down the Court of Justice? The dynamics between network implementation and Article 258 TFEU litigation' (2014) European Law Journal, 664-5.
} 
Table 1. Legal instruments selected and relevant soft law associated with them

\begin{tabular}{lll}
\hline Area & Directive & Soft law measures \\
\hline Water & Water Framework Directive $^{\mathrm{a}}$ & 34 guidance documents \\
Waste & Waste Framework Directive $^{\mathrm{b}}$ & 1 guidance document \\
Biodiversity & Habitats Directive $^{\mathrm{c}}$ & 15 guidance documents \\
& Birds Directive $^{\mathrm{d}}$ & 1 guidance document \\
Land use & Environmental Impact Assessment (EIA) Directive $^{\mathrm{e}}$ & 16 guidance documents \\
& Strategic Environmental Assessment (SEA) Directive $^{\mathrm{f}}$ & 2 guidance documents \\
\hline
\end{tabular}

${ }^{a}$ Directive 2000/60/EC of the European Parliament and of the Council of 23 October 2000 establishing a framework for Community action in the field of water policy [200] OJ L 327-1. ${ }^{b}$ Directive 2008/98/EC of the European Parliament and of the Council of 19 November 2008 on waste and repealing certain Directives [2008] OJ L 312-3. ${ }^{\circ}$ Council Directive 92/43/EEC of 21 May 1992 on the conservation of natural habitats and of wild fauna and flora [1992] OJ L 206-7. d Directive 2009/147/EC of the European Parliament and of the Council of 30 November 2009 on the conservation of wild birds [2010] OJ L 20-7. ${ }^{\mathrm{e}}$ Directive 2011/92/EU of the European Parliament and of the Council of 13 December 2011 on the assessment of the effects of certain public and private projects on the environment [2012] OJ L 26-1. fDirective 2001/42/ EC of the European Parliament and of the Council of 27 June 2001 on the assessment of the effects of certain plans and programmes on the environment [2001] OJ L 197-30.

The soft law measures stemming from these directives can all be ascribed the category of interpretative rules; there does not seem to be, amongst the soft law measures selected, any decisional instrument. While the first type of measures serves to interpret provisions of binding EU law, the second indicates the manner in which an EU institution intends to exercise its discretion. ${ }^{23}$ The common denominator of these guidance documents is that of explaining how to interpret and apply certain provisions of EU environmental law. By way of example, they provide Member States with guidance on eg the identification of water bodies (CIS-Common Implementation Strategy_Guidance No. 2), the analysis of pressures and impacts (CIS Guidance No. 3), monitoring (CIS Guidance No. 7) etc. in the broad context of the development of integrated river basin management plans as required by the Water Framework Directive.

Their publication as well as translation status varies significantly: many guidance documents are only available in English and on the website of DG environment, while others are translated (often not in all official languages), and have been published in the Official Journal. Moreover, while some are authored by the Commission, others are only 'endorsed' by the Commission and have been prepared by consultants. Their names also change, varying from Guidance Document, Guideline, Communication, Working Document, and so on. ${ }^{24}$

\footnotetext{
${ }^{23}$ Scott (n 17), 1. Admittedly, decisional acts are mostly common in other EU policy fields, such as competition and state aid matters, and less in the environmental policy.

${ }^{24}$ Annex I gives an overview of these criteria for the reviewed soft law measures.
} 
The question central to this paper is how European courts have, in the cases before them, treated soft law. The instances in which this situation may occur are, first of all, in an action for annulment pursuant to Article 263 TFEU of a soft law measure itself, or a hard law provision, where an argument based on a related soft law measure is brought forward or, alternatively in a preliminary question of validity pursuant to Article 267 TFEU. Alternatively, soft law can come to the attention of the court through a preliminary question of interpretation of the soft law measure itself or of a hard law measure related to a soft law instrument on the basis of Article 267 TFEU. Finally, soft law can be referred to infringement proceedings brought by the Commission against a Member State according to Article 265 TFEU. For the purposes of the current analysis, rulings and orders of the CJEU and the General Court as well as opinions of AGs have been considered.

The EU courts could thus be vested directly with the question of reviewing the legality of a soft law provision or solving doubts on its interpretation or could indirectly use soft law for the interpretation of hard law provisions.

This paper aims to provide both a quantitative and a qualitative analysis of the role of soft law before European courts in environmental matters. This research is carried out through a textual analysis of the judgments and orders of the CJEU and the General Court and the opinions of the AGs referring to soft measures. The Civil Service Tribunal has no competence on environmental matters and its case law was therefore excluded. Only closed cases have been selected.

Drawing inspiration from previous work, ${ }^{25}$ it is first assessed to what extent relevant soft law measures are present in the rulings of EU courts', relative to the importance they have for the specific instrument at stake. This research was carried out through the search engine provided on the website of the Court of Justice. ${ }^{26}$ The search was carried out by using the numbers of the relevant Directive, operating under the assumption that when a soft law measure stemming from a certain Directive is used in court, reference is made to the hard law measure which justified the issuing of the soft law measure. Rulings, orders, and opinions which were listed as being relevant, but for which no information was available have been excluded. Rulings, orders, and opinions which were listed as being relevant, but which did not in substance deal with the selected Directives, have equally been excluded. The exclusion covered cases in which one of the relevant Directives was mentioned, but in which the legal problem did not concern the Directive at stake (in the form of, eg, a question of interpretation of a provision of the Directive in a preliminary ruling of interpretation, the nonor wrong transposition of part of the Directive in infringement proceedings).

\footnotetext{
25 Stefan (n 16), especially Appendix 1.

$26<$ http://curia.europa.eu/juris/recherche.jsf?language $=e n>$.
} 
Secondly, where soft law measures are present in the rulings, it is examined how they are treated by the courts, ie what status and legal effects are recognized in them.

\section{Quantitative analysis}

Table 2 shows the results of the search as carried out in the search engine provided in the website of the Court of Justice. ${ }^{27}$

Table 2. Total number of cases concerning the selected legal instruments and number of cases in which the relevant guidance documents are mentioned

\begin{tabular}{lll}
\hline & $\begin{array}{l}\text { Total number } \\
\text { of cases }\end{array}$ & $\begin{array}{l}\text { Number of cases } \\
\text { where soft law } \\
\text { is mentioned }\end{array}$ \\
Directive & 28 & 2 (in AG opinions) \\
Water Framework Directive & 17 & 0 \\
Waste Framework Directive & 97 & 11 (8 in AG opinions \\
Habitats Directive & 84 & 0 and 3 in rulings) \\
Birds Directive & 89 & 0 (in AG opinions) \\
Environmental Impact Assessment (EIA) Directive \\
Strategic Environmental Assessment (SEA) Directive
\end{tabular}

Table 2 shows, first of all, that relative to the total number of cases relating to the selected Directives, soft law plays a rather minor role. Despite, therefore, its alleged importance for the Commission and national administrations, soft law is not often invoked or discussed before the European courts. Also, it is mostly discussed by Advocate Generals, and much more rarely taken up in the actual rulings. This stands in contrast with eg competition and state aid policy, where soft law references by the European Courts and the Advocates General are much higher. ${ }^{28}$

Secondly, looking at the time span, it can be observed that reference to soft law is a rather recent phenomenon: despite, for example, the Habitats Directive being in existence for more than 20 years, soft law was not was referred to in court in a preliminary question concerning the interpretation of the Directive before 2004. This trend is in line with other policy fields in which indeed the European Courts have significantly increased their references to soft law over the years. ${ }^{29}$

27 See Annex II for a list of the cases in which the guidance documents are mentioned.

${ }^{28}$ Stefan (n 16), 57-8.

${ }^{29}$ Ibid. 
Table 3 provides a chronological overview of the references to soft law stemming from the selected EU measures.

If one compares this information with the years in which the selected soft law was adopted, this result is not surprising, as the phenomenon of guidance documents also seems to be a relatively recent one. This is also the case for older Directives, such as the EIA Directive. ${ }^{30}$

Table 4 provides an overview of the years of enactment of the selected soft law measures, subdivided according to the underlying Directives.

Table 3. Chronological overview of references to selected soft law measures

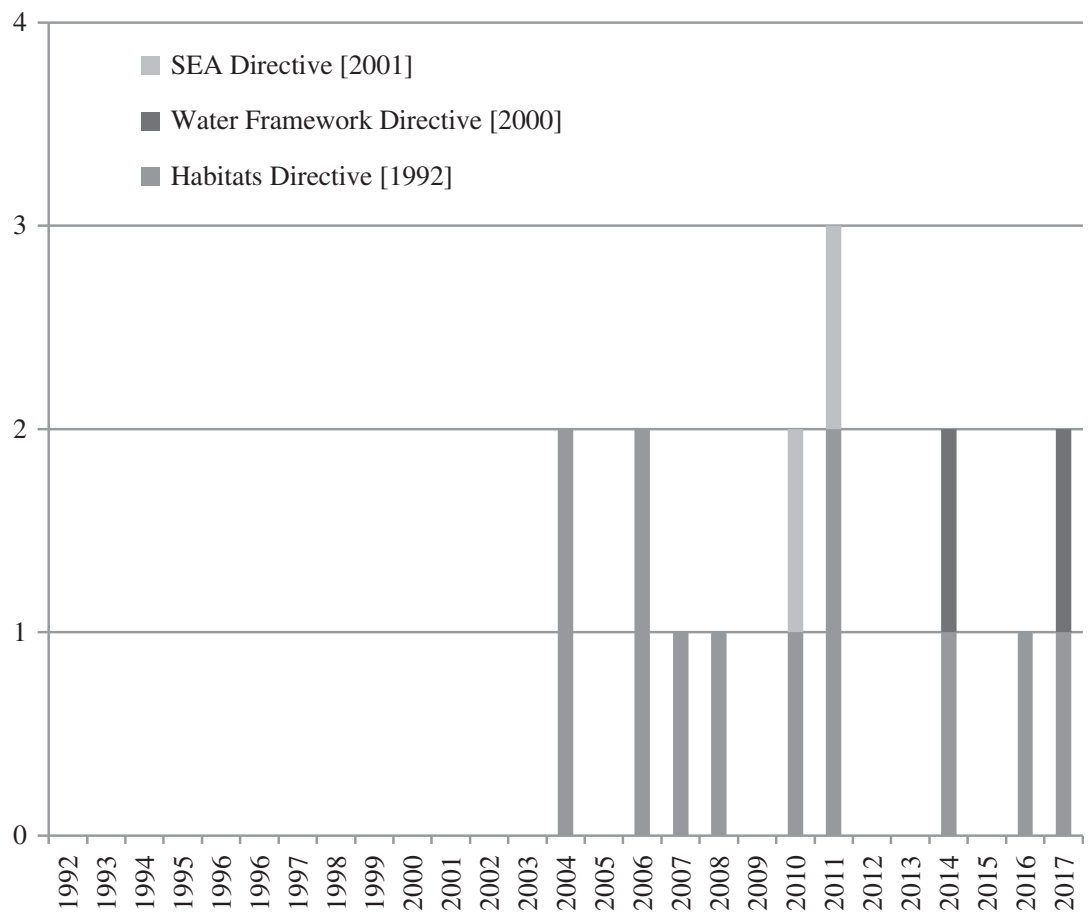

${ }^{30}$ Compare here the results of Stefan (n 16), $77 \mathrm{ff}$. Please note that for one guidance document stemming from the SEA Directive, the document contained no indication of the year hence it was not included in this table. 
Table 4. Year of enactment of the selected soft law measures

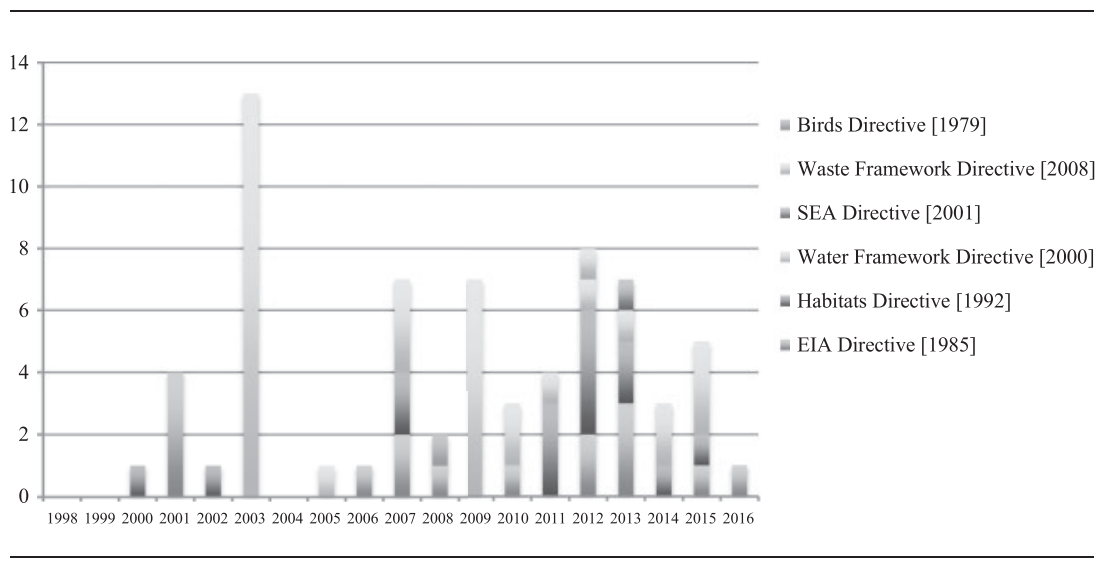

Thirdly, the actual number of guidance documents or of rulings concerning a specific Directive does not seem to be correlated to the use of soft law in court. While the Water Framework Directive is the instrument with most guidance documents, soft law relating to it was discussed in only two cases. Similarly, the EIA Directive has often been the subject matter of claims before the European Courts, but the guidance documents stemming from it seem never to have been discussed before the European Courts.

Nor can one observe a link between the 'age' of the Directive and the use of soft law. The EIA Directive is older than the Habitats Directive and yet the European Courts never discussed the supporting guidance documents in the cases brought before them.

Interestingly, the 'experimentalist' and vague nature of the instrument also does not increase the use of soft law made by the European courts. This is, as such, a very counterintuitive observation, as one would expect an increased use of guidance documents by the European courts in respect to legislative measures which contain openended key provisions. By way of example, many of the key terms of the Water Framework Directive (as 'key' as the one concerning the definition of 'good water status') are not defined in the Directive itself and only specified in the ensuing soft law. One might expect, therefore, that the Court of Justice would use these soft law measures which, it may be argued, are an essential part of the legislative measure itself.

\section{Qualitative analysis}

\section{A. The justiciability of soft law}

If one looks at the types of cases in which soft law has been at stake, the first striking observation is that no action for annulment or preliminary question of 
validity has been brought against a soft law measure itself. Without being able to give conclusive evidence for this statement, one of the reasons for this absence could be related to the strict admissibility conditions set by the Court of Justice, which would have barred a claim against a guidance document.

First of all, as noted by Scott, in order to be reviewable, a measure needs to be an act adopted by the European institutions pursuant to Articles 263 and 267 TFEU, and it is likely that guidance documents which have been adopted jointly by the Commission and the Member States, will not meet this criterion. ${ }^{31}$ This would automatically exclude from challenge the guidance documents issued, for example, in the context of the Water Framework Directive, since the emphasis in these documents is put on joint authorship. Despite the Commission's active role in the drafting of these documents, it has been considered unlikely that for the guidance stemming from the Water Framework Directive, the Court of Justice will not readily consider the EU authorship requirement fulfilled. ${ }^{32}$

The authorship requirement, however, seems far from clear when analysing the case law of the Court of Justice beyond the environmental field, and there is at the very least scope for doubt as to whether a claim against certain guidance documents drafted in cooperation between the Commission and the Member States will be considered admissible.

For example, in Deutsche Shell, the Court of Justice considered the nature of the recommendations adopted by a Joint Committee created within the framework of a Convention in force between the Community and the EFTA countries. ${ }^{33}$ In this case, the Court held that 'measures emanating from bodies which have been established by an international agreement of that type, and which have been entrusted with responsibility for its implementation, are directly linked to the agreement which they implement, they form part of the Community legal order'. ${ }^{34}$ Similarly, in another case concerning the decisions of an Association Council, created by the EU Turkey Association Agreement, the Court held that ' $[S]$ ince the Court has jurisdiction to give preliminary rulings on the Agreement, in so far as it is an act adopted by one of the institutions of the Community ..., it also has jurisdiction to give rulings on the interpretation of the decisions adopted by the authority established by the Agreement and entrusted with responsibility for its implementation'. 35 Finally, in the recent James Elliott case, the Court of Justice declared itself to have jurisdiction to interpret standards adopted by the European standardization bodies, because these measures, although they are adopted by private bodies

\footnotetext{
31 Scott (n 17), 337.

32 E Korkea-aho, Adjudicating New Governance (Abingdon: Routledge, 2015), 173-4.

33 Case C-188/91, Deutsche Shell AG v Hauptzollamt Hamburg-Harburg ECLI:EU:C:1993:24.

34 Ibid, para. 17.

35 C-192/89, Sevince v Staatssecretaris van Justitie ECLI:EU:C:1990:322, para. 10.
} 
and only 'endorsed' by the Commission, are taken to be an implementation of EU law. ${ }^{36}$

Although these rulings are not specific to the field of environmental law and do not concern annulment actions, it could nevertheless be argued, on the basis of this case law, that the Court might be willing to go beyond a strict interpretation of the authorship criterion at least for those soft law measures which directly stem from secondary EU law measures.

For guidance documents which might be considered as stemming solely from the Commission (such as those issued in the context of the Habitats Directive), and for which, therefore, the authorship requirement does not constitute a hurdle to the admissibility of a claim against them, their justiciability, at least in terms of direct actions, will be limited by a second condition imposed by the Court of Justice.

In order for an act to be reviewable, it must be intended to produce legal effects vis-à-vis third parties' according to Article 263 TFEU and the Court of Justice's case law. ${ }^{37}$ This has been held to be the case when guidance is construed as introducing a new obligation, ${ }^{38}$ where a soft law measure states the way in which an EU institution intends to exercise its discretion, ${ }^{39}$ or, as far as Member States are concerned, where the soft law measure at stake has been produced in cooperation with the Member States. ${ }^{40}$

It is very likely that the guidance document issued in the framework of the selected Directives will not fulfil any of the three above mentioned requirements for admissibility. Leaving the first requirement aside for the moment, with regards to the second requirement, the guidance documents stemming from the selected Directives constitute interpretative aid, and mostly for Member States, thus one cannot find situations of a guidance document containing statements of how in particular the European Commission is going to exercise its discretion.

Concerning the third requirement, while it is true that for many of the guidance documents which fall within the scope of this paper, Member States have been consulted or have even cooperated in the drafting of the documents and endorsed them, this circumstance will not render them justiciable. This is

\footnotetext{
${ }^{36}$ C-613/14, James Elliott Constructions Limited v Irish Asphalt Limited, ECLI:EU:C:2016:821, para. 34: 'the Court has jurisdiction to interpret acts which, while indeed adopted by bodies which cannot be described as "institutions, bodies, offices or agencies of the Union", are by their nature measures implementing or applying an act of EU law'. See for a comment to this case, C Colombo and M Eliantonio, 'Harmonized technical standards as part of EU law: Juridification with a number of unresolved legitimacy concerns? Case C-613/14 James Elliot Construction Limited v. Irish Asphalt Limited, EU:C:2016:821' (2017) Maastricht Journal of European and Comparative Law, 323-40.

37 Case 22-70, Commission v Council ECLI:EU:C:1971:32, para. 42.

38 Case C-366/88, France v Commission (Internal Instructions) ECLI:EU:C:1990:348.

39 Joined Cases C-189/02 P, C-202/02 P, C-205/02 P, C-208/02 P, and C-213/02 P, Dansk Rørindustri and Others $v$ Commission ECLI:EU:C:2005:408.

40 Case C-311/94, Ijssel-Vliet Combinatie BV v Minister van Economische Zaken ECLI: EU:C:1996:383.
} 
because Member States' acceptance of a soft law instrument is not itself a sufficient element for its justiciability: what is crucial is that a measure has been adopted in the framework of a specific cooperation obligation between the Member States and the Commission, ${ }^{41}$ which is not the case with the soft law instruments analysed in the context of this article. This conclusion, however, creates a rather artificial differentiation vis-à-vis many environmental soft law measures which, despite being adopted in a negotiated context, do not fit the strict Ijssel-Vliet requirements, and therefore profit from a sort of 'immunity' from judicial review.

In respect of the first requirement, it is invariably the case that the guidance documents at stake contain disclaimers as to their non-binding nature and that they do not intend to create any new obligations. However, as discussed for the Water Framework Directive (but the argument is equally applicable to other measures which contain vague requirements and do not necessarily present an 'experimentalist' nature, such as Article 6 of the Habitats Directive), it is very hard to draw a line between 'fleshing out' ${ }^{42}$ existing obligations, or rendering obligations 'more explicit' 43 on the one hand, and creating new obligations, on the other hand. ${ }^{44}$ This renders the legal effects criterion difficult to apply and its outcome rather unpredictable.

The production of legal effects, however, seems not be a necessary requirement in a preliminary question of validity. Indeed, with regard to the scope of the Court's jurisdiction in preliminary questions of validity, in Grimaldi, which concerned a piece of soft law, namely a Commission Recommendation, the Court of Justice held that '[I]t is sufficient to state in that respect that, unlike Article 173 of the EEC Treaty, which excludes review by the Court of acts in the nature of recommendations, Article 177 confers on the Court jurisdiction to give a preliminary ruling on the validity and interpretation of all acts of the institutions of the Community without exception'. ${ }^{45}$ Although the broad jurisdiction of the Court of Justice in validity questions has recently been questioned by AG Cruz Villalón in the Gauweiler case, the statement in Grimaldi has, as such, never been retracted by the Court of Justice and therefore still constitutes good law. ${ }^{46}$ In this context, it must be added that the reference made by the AG to the Friesland case $^{47}$ does in fact seem to corroborate rather than weaken this conclusion. In this case, indeed, the Court reiterated the above mentioned

\footnotetext{
41 Ibid para. 44.

42 Case C-325/91, France v Commission ECLI:EU:C:1993:245, para. 14

43 Case C-366/88, France v Commission ECLI:EU:C:1990:348, para. 23.

${ }^{44}$ Korkea-aho (n 32), 175.

45 Case C-322/88 Salvatore Grimaldi v Fonds des maladies professionnelles ECLI:EU:C:1989:646, para. 8. On Grimaldi and its consequences, see E Korkea-aho, in this Special Issue.

46 AG Cruz Villalón, Case C-62/14, Peter Gauweiler and others $v$ Deutscher Bundestag ECLI:EU:C:2015:7, on which see further, J Alberti, in this Special Issue.

47 Case C-11/05, Friesland Coberco Dairy Foods BV v Inspecteur van de Belastingdienst/Douane Noord/ kantoor Groningen EU:C:2006:312, paras 34-42.
} 
paragraph of Grimaldi concerning the broad jurisdiction of the court in validity questions, and dismissed the question of a preliminary ruling not on the alleged lack of legal effects of the measure at stake, but on the authorship criterion.

Hence, it can be concluded that the lack of judicial protection in cases of a direct challenge of guidance documents could be partially filled through an indirect challenge pursuant to Article 267 TFEU. ${ }^{48}$

\section{B. Soft law as an interpretational tool}

The validity of the soft law selected for this contribution has therefore never challenged, its presence being detectable before the European Courts only in interpretation, and overwhelmingly so in preliminary questions of interpretation and, less so, in infringement proceedings. In only one annulment case did the European courts refer to soft law, when the annulment of a hard law provision was at stake and soft law was used for interpretation purposes.

In a case concerning the Water Framework Directive, ${ }^{49}$ when dealing with the legal issue at stake, ie the interpretation of the concept of 'deterioration', the AG refers in his last argument to a specific Guidance Document which, he states, has been mentioned by 'several parties' to the proceedings. Despite making use of this document, the AG highlights that the document in itself has no binding value. In order to support the non-binding force of the guidance document at stake, he adds that the document is not 'a communication of the Commission within the meaning of the case-law in the field of competition law or the law on financial penalties', ${ }^{50}$ thereby making reference to the category of 'decisional acts' which the Court has long considered binding on the issuing institution. ${ }^{51}$ This statement almost seems to suggest that the field of competition law and the soft law adopted in this policy area are to be regarded as peculiar cases, and the case law concerning the effect of soft law adopted in competition policy is not to be extended to other policy fields.

Similarly, in an infringement case concerning the question of whether France had taken sufficient measures to protect the European hamster as required by the Habitats Directive, the AG refers extensively to a Guidance Document supporting the Habitats Directive, and states that, although not binding, it 'contains useful guidance on the interpretation of the relevant provisions'. ${ }^{52}$ The AG thus incorporates soft law in her considerations to reach her

\footnotetext{
${ }^{48}$ See also E Korkea-aho in this Special Issue, who makes reference to the Kotnik and Others case to support this statement. Case C-526/14, Kotnik and Others, ECLI:EU:C:2016:570.

49 Opinion of Advocate General in case C-461/13, Bund für Umwelt und Naturschutz Deutschland ECLI:EU:C:2014:2324.

${ }^{50}$ Ibid, para. 107.

51 See C-189/02 P, C-202/02 P, C-205/02 P to C-208/02 P and C-213/02 P Dansk Rørindustri and Others $v$ Commission, EU:C:2005:408, paras 211-213.

52 Opinion of Advocate General in case C-383/09 European Commission v French Republic ECLI:EU:C:2011:23, para. 28.
} 
conclusions on France's alleged non-compliance with the Directive, but she keeps the non-binding nature of the Guidance Document clear.

The same can be observed with regard to the AG opinion in the Waddenvereniging and Vogelsbeschermingvereniging case. ${ }^{53}$ The Guidance Document 'Managing Natura 2000 Sites' in this case plays a prominent role in the opinion of the Advocate General, who refers to the document on several occasions, but mostly only with regard to the submission of the parties: first, to support the interpretation of the concepts of 'plan or project' in the Habitats Directive; ${ }^{54}$ secondly, to distinguish the scope of application of Articles 6(2) and (3) of the Directive; ${ }^{55}$ and thirdly, to support the interpretation of the concept of 'adverse effects'. 56

It is only in one place of the actual opinion that the AG referred to two Guidance Documents issued in the context of the Habitats Directive: while stating that the Habitats Directive does not lay down any methods for carrying out an appropriate assessment, he adds that it may be helpful to refer to the relevant documents of the Commission [ie two supporting Guidance Documents] even though they are not legally binding' 57

Although not mentioning the expression 'non-binding', the AG expressed the same concept in an infringement case against Ireland, where he clearly stated that a Guidance Document issued under the Habitats Directive cannot in any way call into question the scope of the obligations stemming from the Directive itself. $^{58}$

In other cases soft law is taken up as an interpretation aid, without mentioning its non-binding nature.

In one case, for example, the AG used a Guidance Document issued for the implementation of the Habitats Directive in the context of explaining the legislative framework. Soft law was thus taken up by the AG in the explanation of the legislative framework as much as the Habitats Directive itself and the Court's case law. ${ }^{59}$ In a similar fashion, in the context of the Water Framework Directive, the AG referred to a Guidance Document in a footnote in order to explain the meaning of a certain provision of the Directive, thereby incorporating the relevant soft law measure in the entirety of the legislative framework at stake. ${ }^{60}$ Interestingly, in the same footnote, the AG refers to the technical difficulties linked to the interpretation and application of the relevant

\footnotetext{
53 Opinion of Advocate General in case C-127/02, Waddenvereniging and Vogelsbeschermingvereniging ECLI:EU:C:2004:60.

54 Ibid para. 21.

55 Ibid para. 46.

56 Ibid para. 79.

57 Para. 95.

58 Opinion of Advocate General in case C-183/05, Commission v Ireland ECLI:EU:C:2006:597.

59 Opinion of Advocate General in case C-521/12, T.C. Briels and Others ECLI:EU:C:2014:113.

${ }^{60}$ Opinion of Advocate General in case Case C-529/15, Gert Folk v Unabhängiger Verwaltungssenat für die Steiermark ECLI:EU:C:2017:1.
} 
article of the Water Framework Directive, implying that the Guidance Documents play an essential role in the implementation of the Directive, a point which has previously been raised in scholarship. ${ }^{61}$

In another case, the AG extensively used a Guidance Document issued to support the implementation of the SEA Directive in order to answer the question of whether a Member States is required to establish a separate authority other than the decision-making authority to fulfil the consultation requirements provided by the SEA Directive. ${ }^{62}$ Drawing a positive answer, the AG went on to state that Member States have a broad margin of discretion under the Directive to organize the environmental consultation procedure. In this context, and to give flesh to the possible options available to Member States, the AG extensively referred to the supporting Guidance Document.

The Guidance Document supporting the implementation of the SEA was also used by the AG in another case, albeit in rather 'tentative' terms, to explain how the likely effects on the environment for the purposes of the obligation to carry out an SEA are to be evaluated. ${ }^{63}$

In an infringement case against Finland with regard to the Habitats Directive, the AG referred to soft law in the context of the interpretation of the derogations from the legal prohibitions relating to the protection of species in order to protect human life and human health. ${ }^{64}$ In this context, the AG supported Finland's interpretation, which had made reference to a supporting Guidance Document. In particular, the AG used the Guidance Document to distil the Commission's interpretation of the provision at stake without referring to its legal value.

Interestingly, this is one of the only three cases in which soft law has been referred in an actual CJEU's ruling. In this context, the Court was called to decide whether killing a limited number of specimens could be regarded as having an adverse effect on the objectives envisaged by the Habitats Directive. The Court in that instance '[F]ollow[ed] the example of the views formulated by the Commission'. ${ }^{65}$ In this context it seemed to use the relevant guidance document as one of the arguments for its interpretation but not as the most important or authoritative one.

It is difficult to draw conclusions from this case law. Whether these cases signify the beginning of a trend of European Courts becoming more engaged with soft law as an interpretational tool in environmental cases is hard to predict. What seems to be the case, however, is that the European Courts (and

\footnotetext{
61 Korkea-aho (n 32), 178.

62 Opinion of Advocate General in case C-474/10, Seaport (NI) and Others ECLI:EU:C:2011:490.

63 Opinion of Advocate General in case C-105/09, Terre wallonne and Inter-Environnement Wallonie ECLI:EU:C:2010:120.

${ }^{64}$ Opinion of AG General in case C-342/05 European Commission v Finland ECLI:EU:C:2006:752, para. 52.

${ }_{65}$ C-342/05 European Commission v Finland ECLI:EU:C:2006:752, para. 29.
} 
especially the Advocates General) do feel free to use guidance documents in their reasoning when this serves the purpose of clarifying the meaning of the relevant Directives. However, soft law is used as one amongst several interpretation tools and in no case is it attributed a special authoritative force.

\section{Soft law and legal effects}

It is only in two cases that soft law seems to have been endowed with legal effects, both times only by AGs.

In the Nomarchiaki case, ${ }^{66}$ for example, the AG used a Guidance Document issued to support the implementation of the Habitats Directive. In particular, dealing with the potential for a plan or project to be implemented for overriding reasons of public interest in spite of the negative environmental consequences, the AG examined the wording of Article 6(4) of the Habitats Directive and, in this context, referred to the Commission 'having publicly expressed its position' on the scope of that provision. Reference was then made to the supporting Guidance Document. It seems, therefore, that the AG was essentially stating that the existence of the Guidance Document has a self-binding effect on the Commission to the extent that the opinion on the plan or project required by Article 6(4) of the Habitats Directive is no longer necessary. The AG in this case appeared to attach a Dansk Rørindustri-like effect to the relevant Guidance Document.

Is soft law not only self-binding on the Commission, but somehow also binding on national authorities? In the Sablstedt case, ${ }^{67}$ the AG used a Guidance Document stemming from the Habitats Directive in order to explain how the margin of discretion of the national authorities in connection with the implementation of the Directive is rather limited. In this context, he stated that, through the Guidance Document, the European Commission has further limited the discretion of the national authorities compared to the limits set in Article 6 of the Directive. In this opinion, which can be regarded as straining the principle of legality, the AG seems to disregard the formally non-binding nature of the guidance document and, in a way, to assume that national authorities will follow the document thereby reducing the margin of their discretion.

These two cases do not constitute a wide enough sample to allow us to draw a conclusion, and the AGs opinions were not taken up in the subsequent courts' rulings. However, they could perhaps be taken as signifying that, in the environmental field, guidance documents could, in certain circumstances, be endowed with legal effects.

${ }^{66}$ Opinion of Advocate General in case C-43/10, Nomarchiaki Aftodioikisi Aitoloakarnanias and Others ECLI:EU:C:2011:651.

67 Opinion of Advocate General in case C-362/06 P, Sablstedt and Others v Commission ECLI:EU:C:2008:587. 


\section{Conclusions}

The analysis carried out in this paper shows that, in the environmental field, at least as far as the selected Directives are concerned, soft law has hardly been referred to, and has mostly been referred to by AGs. This low number of references stands in contrast to other areas, such as competition and state aid cases. One of the possible reasons for this low number of references may be that many of the selected guidance documents (as is the case of, for example, the EIA Directive) consolidate prior case law of the Court of Justice. The latter may thus continue to refer to its earlier case law instead of the relevant guidance document. This phenomenon is very hard to test methodologically, because it would entail not only a detailed knowledge of the technical aspects of the texts involved, ${ }^{68}$ but also the need to carry out interviews with judges on the decisional process leading up to the rulings at stake. ${ }^{69}$ And even where interviews were carried out, the conclusions drawn might be partial given the secrecy requirement of judicial deliberations.

Furthermore, it appears that the attitude of the European Courts and AGs towards soft law is relatively random and $a d$ hoc. Soft law is used and referred to when needed (mostly for interpretational purposes), but there does not seem to be any conceptualization behind the use of soft law in Luxembourg, at least insofar as environmental policy is concerned.

Another interesting conclusion is that soft law references seem to be a relatively new phenomenon, and one that is unrelated to the number of rulings concerning the Directive, the number of guidance documents issued concerning a Directive, the age of the Directive, its procedural, substantive, or experimentalist nature.

Moreover, it can be observed that no action for annulment has been brought against the guidance documents stemming from the selected Directives. Such an action would likely not be admissible, first, because of the authorship requirement, as Member States often cooperate with the Commission in the production of these measures. Secondly, in light of a consolidated line of case law, the guidance documents at stake would probably not be considered by the Court of Justice as being capable of producing legal effects.

Given such a high bar to admissibility, should an action against a guidance document (for possible violation of, eg, the underlying Directive or a general principle of EU law) be brought, it would constitute a significant limitation to the judicial oversight of soft law, for (at least some of) the reasons which Scott has highlighted..$^{70}$ First of all, these guidance documents produce significant

\footnotetext{
${ }^{68}$ See further on this point, A Beckers, in this Special Issue.

${ }^{69}$ Please note that an empirical analysis on the use of EU soft law by national courts is being undertaken in the framework of a Commission-financed Jean Monnet Network. For more details see www.solar-network.eu

${ }^{70}$ Scott (n 17), 344-5.
} 
practical effects because Member States tend to comply with them. Secondly, guidance documents may shape and influence the Commission's enforcement approach. Thirdly, a bar to judicial review constitutes a missed opportunity to review soft law's often intransparent adoption procedure.

In the increasingly common situations of joint authorship and framework norms, it would therefore be advisable for the European Courts to look beyond the surface and engage in a review of soft law, possibly through the use of earlier case law which seems to have departed somewhat from a strict interpretation of what constitutes 'an act of the EU institutions'.

Even if there were no change in the case law with regard to direct actions, one possible way to fill this gap in judicial review, at least for those guidance documents which could overcome the authorship hurdle, would be the possibility of an indirect review of soft law measures through a preliminary question of validity in accordance with Article 267 TFEU. Since the overwhelming majority of the guidance documents stemming from the selected Directives are addressed to Member States in order to guide their transposition and application process, it would be possible for a claim to be brought before a national court against a national measure taken in application of the Directive and thereby to contest Member State action for application of an allegedly unlawful guidance document. The national court, bound by the Foto-Frost limitation, ${ }^{71}$ would have to send a preliminary question to the Court of Justice. Unlike the position argued by Scott, ${ }^{72}$ I think such a possibility is a real one, given the wide scope of preliminary questions of validity given by the Court of Justice in Grimaldi, which encompasses all 'acts of the EU institutions'.

A further conclusion which can be drawn from the analysis carried out in this article is that the AGs have in some cases used soft law issued in the context of the interpretation of the selected Directives, yet its use is limited and almost absent in the European Courts' rulings.

The follow-up question is whether, in light of the regulatory framework which environmental measures increasingly display, environmental soft law ought to be considered more often in court as interpretational tool. As guidance documents are frequently issued in cases of vaguely formulated standards and norms, it is hard to accept that the vague legislation should be reviewed in court without its subsequent fleshing out in guidance documents. The risk is that rulings would 'fail to take into account the real content and the context of implementation' ${ }^{73}$ In other words, if the institutional setup in essence 'calls for' guidance in the form of soft law for the purposes of implementation of an EU obligation, it seems short-sighted to ignore a relevant piece of information concerning the implementation of that obligation. This does not mean, as

71 Case 314/85 Foto-Frost v Hauptzollamt Lübeck-Ost ECLI:EU:C:1987:452.

72 Scott (n 17), 345.

73 Korkea-aho (n 32), 178. 
Korkea-aho explains, curtailing judicial independence in interpreting EU law, but inviting the EU courts to at least discuss the guidance documents which might be relevant for the case at stake and, if they decide to use a different interpretation than therein provided, give reasons for doing so. ${ }^{74}$

Finally, the attitude of the AGs in the Nomarchiaki and Sablstedt cases would seem to indicate that the production of legal effects is not completely excluded in certain situations, which would render certain soft measures justiciable, even according to the current requirements set by the Court of Justice. However, the sample of cases where this seems to have happened is very limited at the moment, and does not allow for any conclusions to be drawn from it.

What can be observed, with regard to the issue of soft law producing legal effects is that, in the vast majority of cases when soft law was referred to, its nonbinding nature has been implicitly or explicitly acknowledged. Therefore, the legitimacy concerns stemming from the possible transformation of soft law into hard law though judicial intervention cannot be maintained, at least as far as the scope of this investigation goes.

${ }^{74}$ Ibid 179-80. 
Soft Law in Environmental Matters and the Role of the European Courts 515

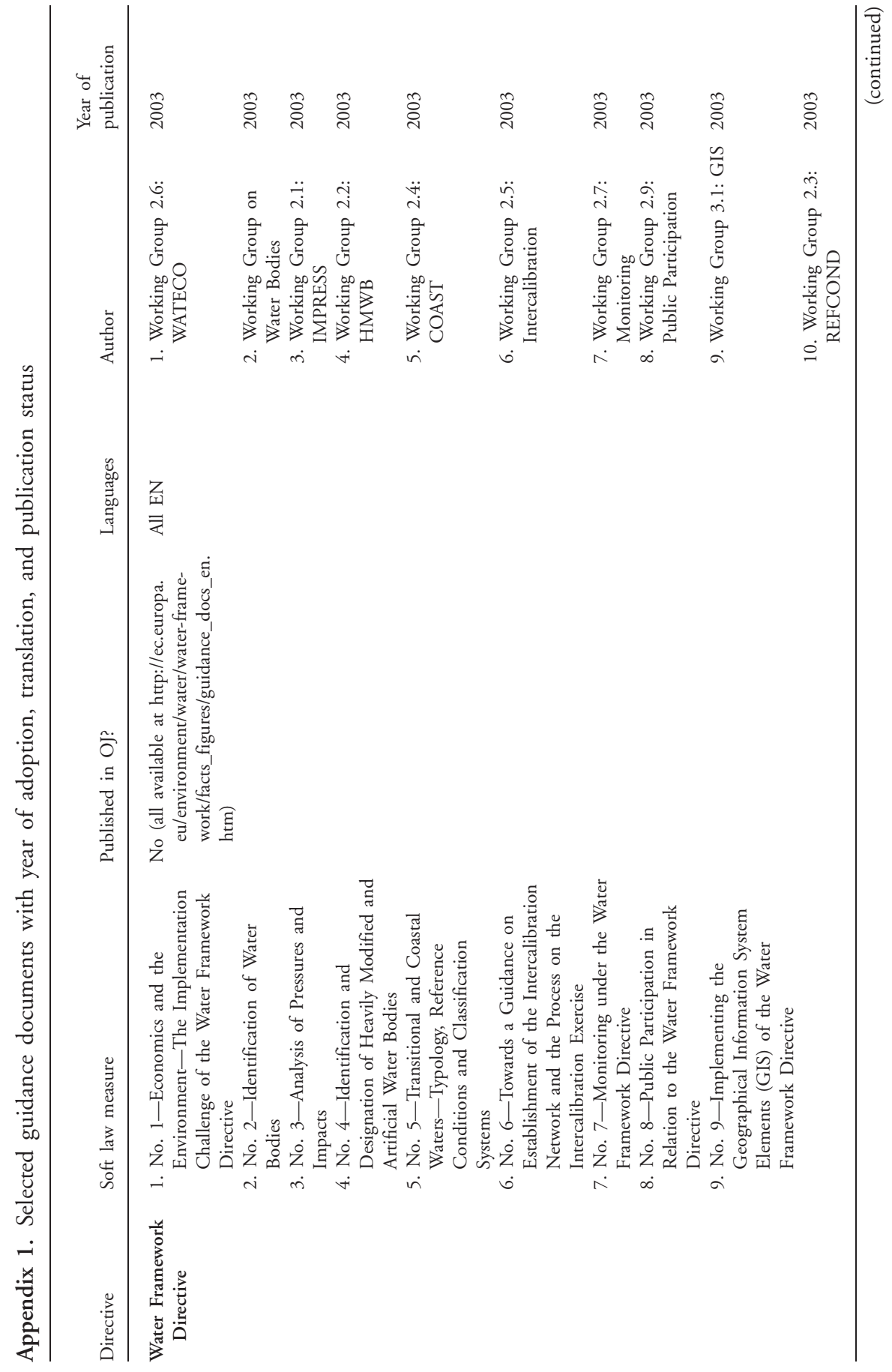




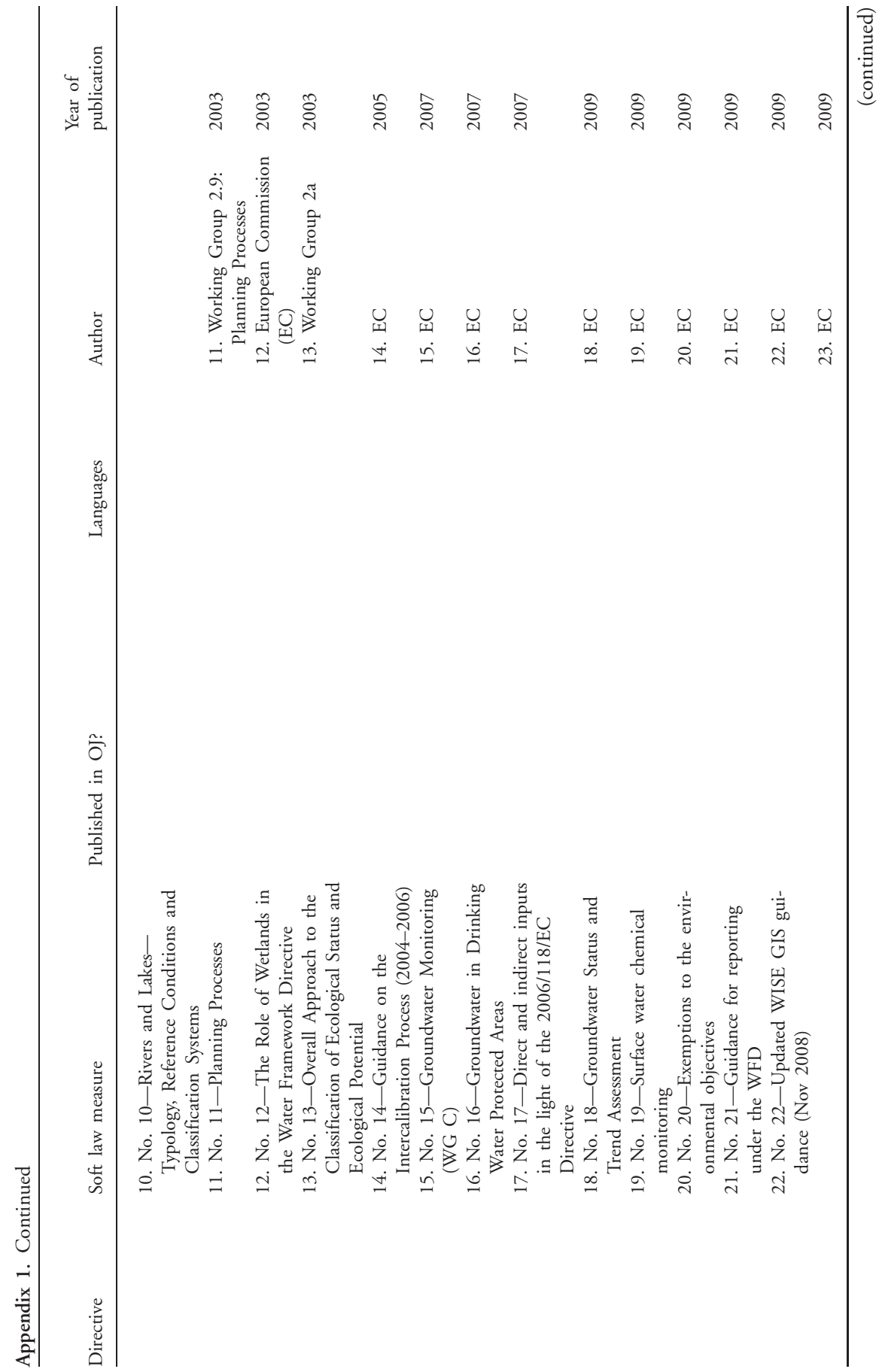


Soft Law in Environmental Matters and the Role of the European Courts 517

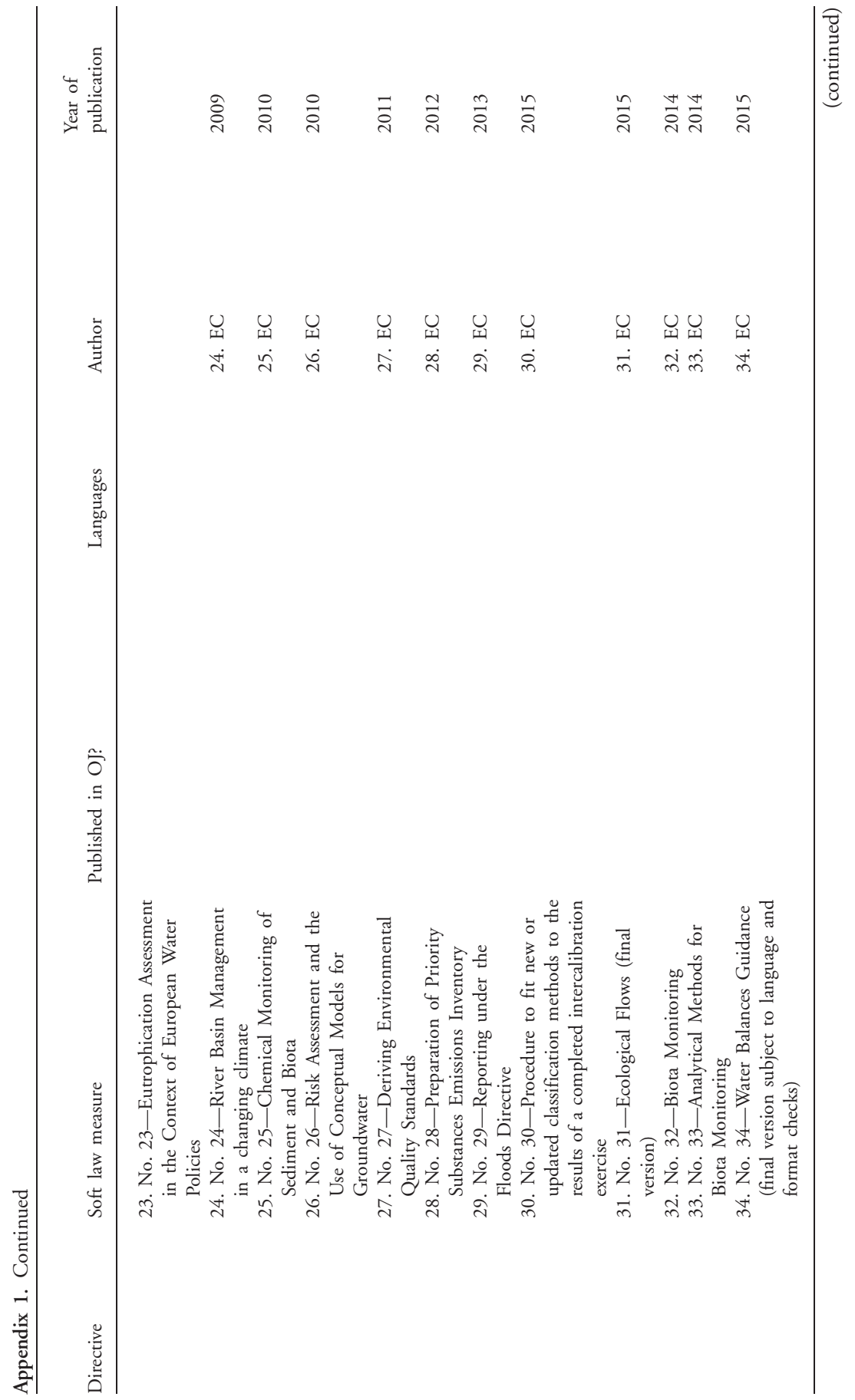




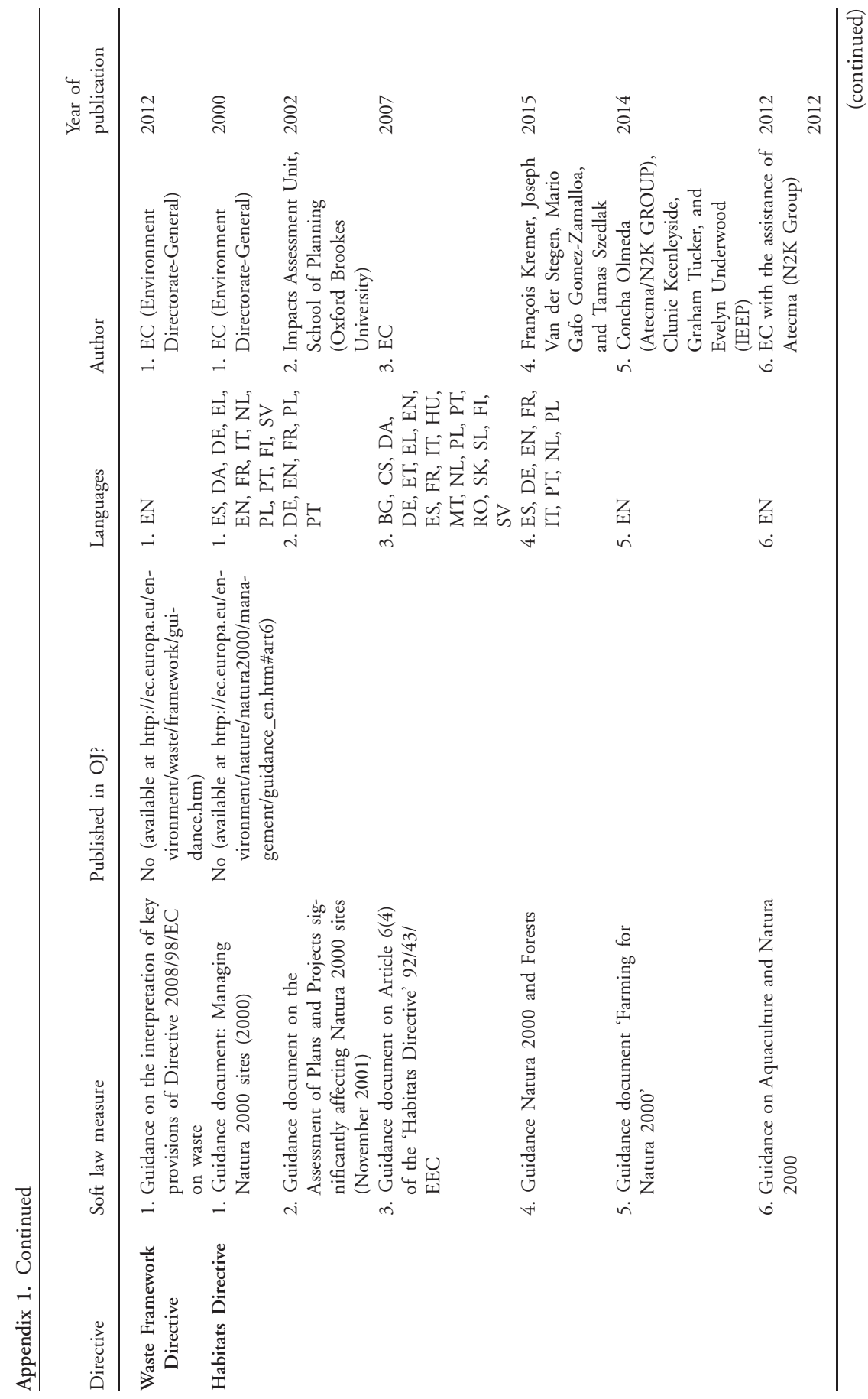


Soft Law in Environmental Matters and the Role of the European Courts 519

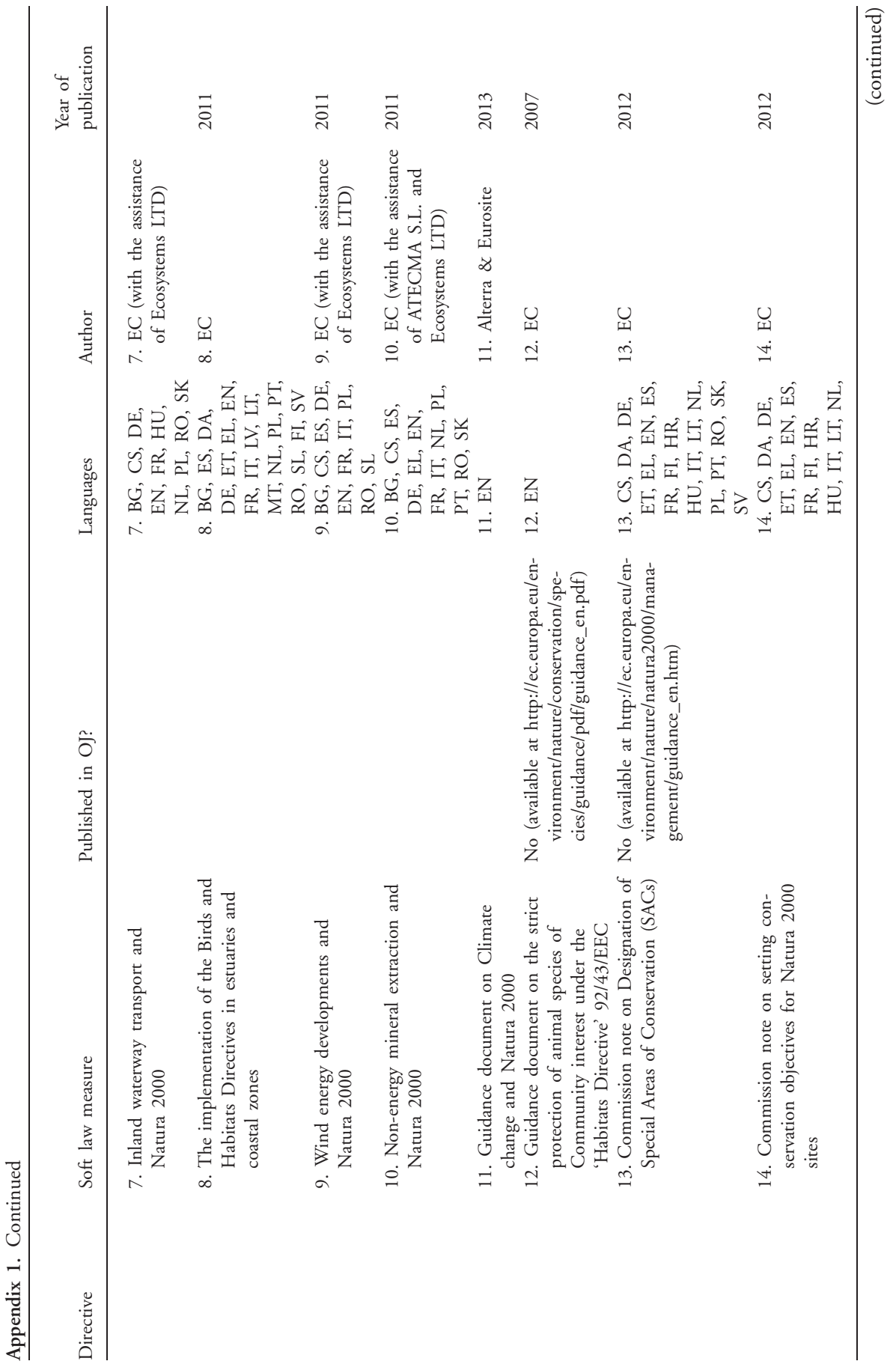




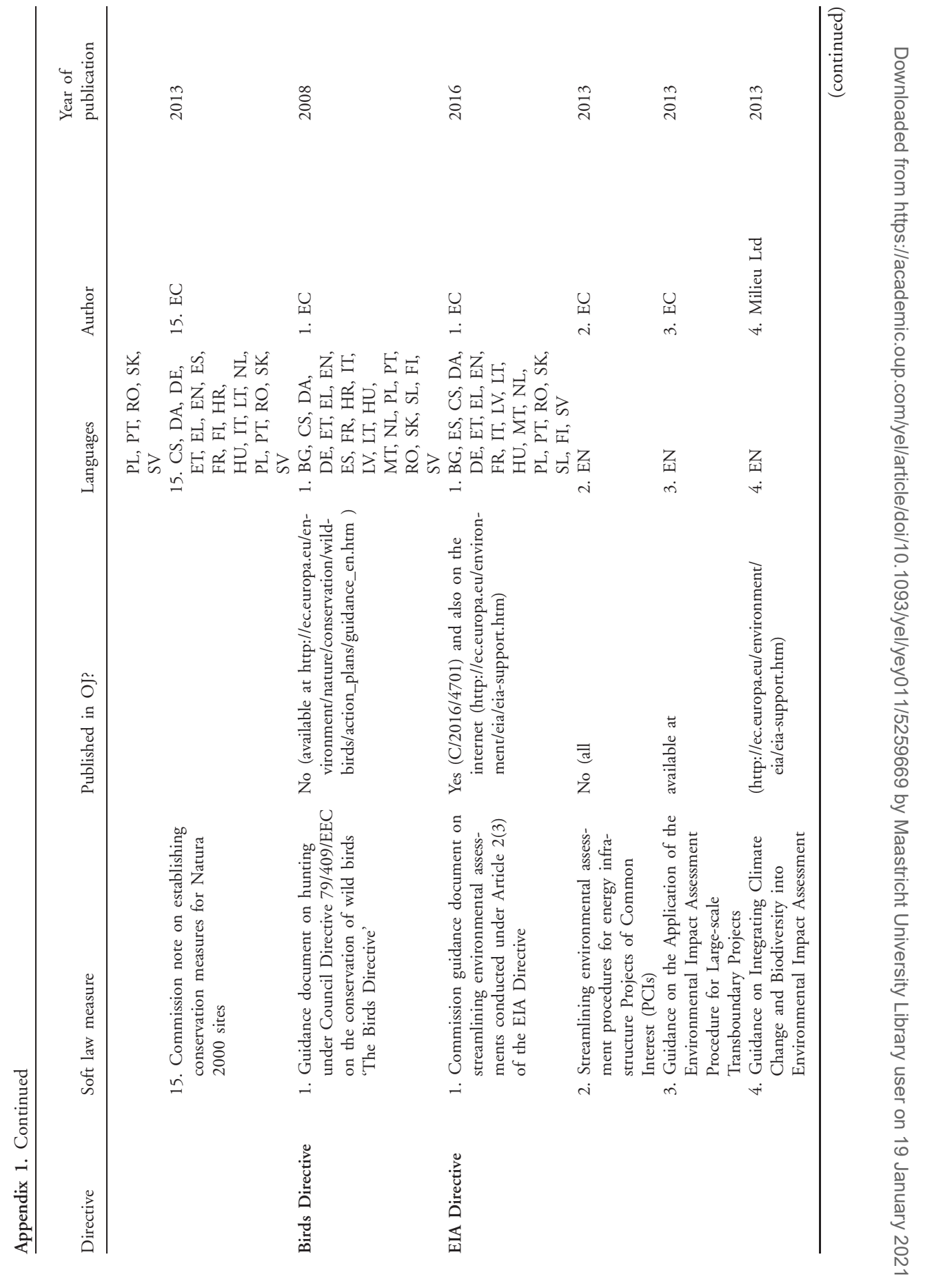


Soft Law in Environmental Matters and the Role of the European Courts 521

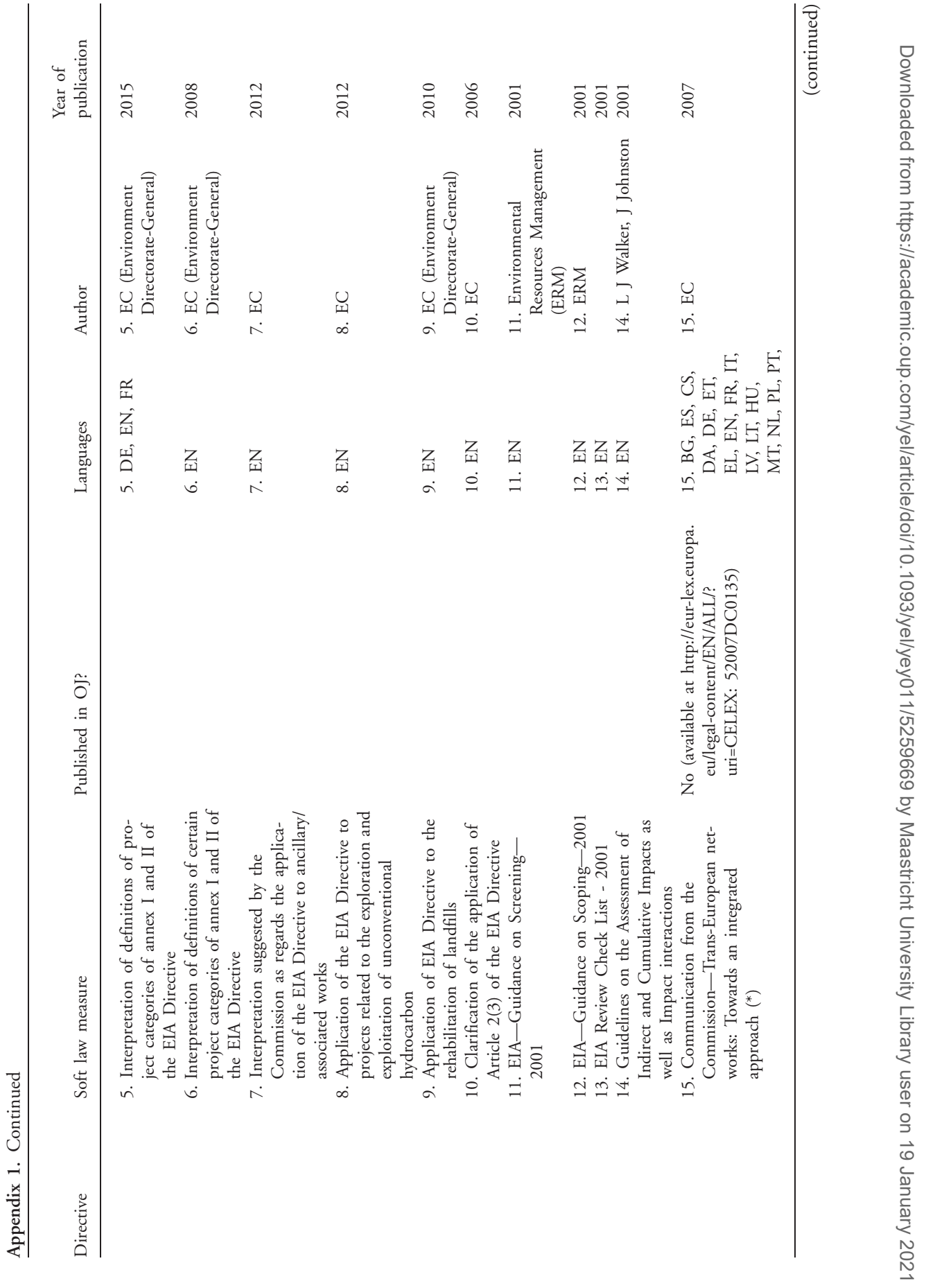




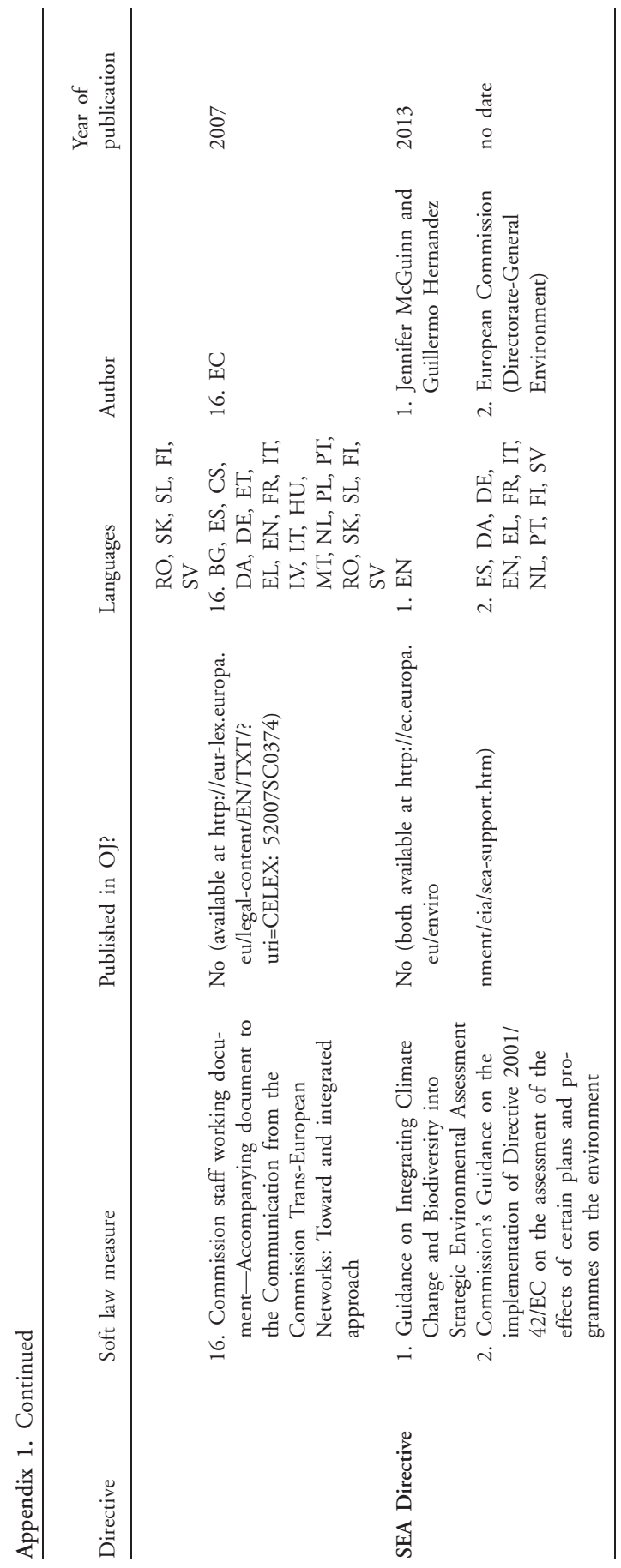


Soft Law in Environmental Matters and the Role of the European Courts 523

\section{Appendix 2 - list of cases in which the selected guidance documents have been mentioned}

Water Framework Directive (Directive 2000/60/EC of the European Parliament and of the Council of 23 October 2000 establishing a framework for Community action in the field of water policy [2000]] OJ L-327/1).

1. C-461/13, Bund für Umwelt und Naturschutz Deutschland, Opinion of Advocate General, ECLI: EU: C: 2014: 2324.

2. C-529/15, Gert Folk v Unabhängiger Verwaltungssenat für die Steiermark, Opinion of Advocate General, ECLI: EU: C: 2017: 1.

Habitats Directive (Council Directive 92/43/EEC of 21 May 1992 on the conservation of natural habitats and of wild fauna and flora [1992] OJ L206/7).

1. C-127/02, Waddenvereniging and Vogelsbeschermingvereniging, Opinion of Advocate General, ECLI: EU: C: 2004: 60

2. C-127/02, Waddenvereniging and Vogelsbeschermingvereniging, Judgment, ECLI: EU: C: 2004: 482

3. C-239/04 - Commission v Portugal, Opinion of Advocate General, ECLI: EU: C: 2006: 255

4. C-183/05, Commission v Ireland, Opinion of Advocate General, ECLI: EU: C: 2006: 597

5. C-342/05, Commission v Finland, Judgment, ECLI: EU: C: 2007: 341

6. C-362/06 P, Sahlstedt and Others $v$ Commission, Opinion of Advocate General, ECLI: EU: C: 2008: 587

7. C-383/09, Commission v France, Opinion of Advocate General, ECLI: EU: C: 2011: 23

8. C-2/10, Azienda Agro-Zootecnica Franchini and Eolica di Altamura, Opinion of Advocate General, ECLI: EU: C: 2011: 252

9. C-43/10, Nomarchiaki Aftodioikisi Aitoloakarnanias and Others, Opinion of Advocate General, ECLI: EU: C: 2011: 651

10. C -521/12, Briels and Others, Opinion of Advocate General, ECLI: EU: C: 2014: 113

11. C-504/14, Commission v Greece, Judgment, ECLI: EU: C: 2016: 847

Strategic Environmental Assessment Directive (Directive 2001/42/EC of the European Parliament and of the Council of 27 June 2001 on the assessment of the effects of certain plans and programmes on the environment [2001] OJ L197/30). 
1. C-105/09, Terre wallonne and Inter-Environnement Wallonie, Opinion of Advocate General, ECLI: EU: C: 2010: 120

2. C-474/10, Seaport (NI) and Others, Opinion of Advocate General, ECLI: EU: C: 2011: 490 